\title{
O poeta da diversidade
}

Regina Zilberman

Pontifícia Universidade Católica do Rio Grande do Sul

O poeta canta a si mesmo

porque de si mesmo é diverso. ${ }^{1}$

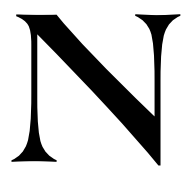

o primeiro soneto de A rua dos cataventos, seu livro de estréia, publicado em 1940, Mario Quintana apresenta em catorze versos a poética que pauta a escrita de seus textos. Abre a primeira estrofe uma declaração: Escrevo diante da janela aberta, como se estivesse aderindo ao programa realista, segundo o qual a literatura traduz a realidade objetiva e exterior ao poeta. O verso seguinte, todavia, desmente a primeira impressão: a caneta do poeta é cor das venezianas, vale dizer Verde!; logo depois, instala-se o clima onírico próximo do Surrealismo: o sol [...] desenha / leves, lindas filigranas [...] na página deserta.

Na segunda estrofe, mesmo a identidade desse segundo autor desaparece, e o poeta confessa:

Não sei que paisagista doidivanas

Mistura os tons... acerta... desacerta...

Sempre em busca de nova descoberta,

Vai colorindo as horas quotidianas...

Diante da poesia produzida pela natureza, o poeta se cala: Do que eu ia escrever até me esqueço..., afirma ele, de que resulta a definitiva imersão no espaço que antes era seu objeto: Pra que pensar? Também sou da paisagem...

A metamorfose, contudo, não terminou: o último terceto revela a derradeira transformação, em que o poeta se converte nesse autor "natural" que até então figurara a ele e ao cenário:

${ }^{1}$ QUINTANA, 1980, p. 117. 
Vago, solúvel no ar, fico sonhando...

E me transmuto... iriso-me... estremeço...

Nos leves dedos que me vão pintando!?

A passagem configura uma assimilação entre sujeito e objeto, mas que não significa a expressão de um eu narcísico, que só enxerga a si mesmo. Pelo contrário, o eu converte-se num outro, objetivo e externo, que visualiza a subjetividade do poeta como exterioridade. A aproximação com um texto de Fernando Pessoa de teor similar esclarece a peculiaridade dessa poética.

"Passos da cruz" é constituído igualmente de sonetos: trata-se de quatorze poemas elaborados conforme as regras desse gênero clássico, que Fernando Pessoa publicou no primeiro e único número da revista Centauro, de Lisboa, em 1916. No Soneto XI, escreve o poeta:

Não sou eu quem descrevo. Eu sou a tela

E occulta mão colora alguem em mim. ${ }^{3}$

Também o poeta português se vê como ser objetivo em que se deposita o objeto de arte, construindo sua identidade. Mas, em verso anterior, Pessoa escrevera: Minha alma beija o quadro que pintou..., ${ }^{4}$ definindo a dimensão narcísica de seu texto.

Não se pode afirmar que Quintana conhecesse os versos de Pessoa, publicados numa revista lisboeta que se restringiu ao volume inicial. Mas ambos experimentaram e acolheram a estética simbolista que está no bojo dessas associações, tanto a que estimula o poeta a se sensibilizar diante das sugestões pictóricas emanadas do cenário, como a que privilegia a expressão do eu em detrimento de temas objetivos, mesmo de teor sentimental, como o amor, a saudade ou a infância, motivos freqüentes nos versos dos românticos.

É transparente a adesão de Pessoa à estética simbolista nos versos de "Passos da Cruz". O primeiro soneto começa com a seguinte estrofe:

${ }^{2}$ QUINTANA, 1972, p. 3.

${ }^{3}$ PESSOA, 1916, p. 73. Edição facsimilada, 1982. Conservamos a ortografia original.

${ }^{4}$ PESSOA, 1916, p. 64. 
Esqueço-me das horas transviadas...

O outomno móra maguas nos outeiros

E põe um rôxo vago nos ribeiros...

Hostia de assombro a alma, e toda estradas...5

Quintana parece responder ao poeta português, quando sugere ser a referência ao outono confissão de adesão a Verlaine, dono, conforme o escritor gaúcho, dessa imagem:

É outono. E é Verlaine... O Velho Outono

Ou o Velho Poeta atira-me à janela

Uma das muitas folhas amarelas

De que ele é o dispersivo dono. ${ }^{6}$

Note-se que as folhas amarelas podem constituir outra maneira de aludir à página, deserta no primeiro soneto de Quintana, agora preenchida pela escrita sugestiva do Simbolismo e de seus numes tutelares, como Paul Verlaine, autor de Fêtes galantes, talvez a obra mais popular do período.

Os vínculos confessos de Quintana com o Simbolismo não se reduzem, em A rua dos cataventos, à menção a Paul Verlaine. Embora não seja usual no gênero poético, Mario não se constrange em fazer citações literárias em vários de seus textos. O soneto XI, dedicado ao português Antônio Nobre e, conforme Quintana, escrito à maneira do mesmo, apresenta o modo como se deu a recepção daquele autor pelo poeta gaúcho quando jovem:

Anto querido, esse teu livro "Só"

Encheu de luar a minha infância triste!

E ninguém mais há de ficar tão só:

Sofreste a nossa dor, como Jesus,

E nesta Costa d'África surgiste

Para ajudar-nos a levar a Cruz!...

No soneto XXIX, Antônio Nobre é matéria dos quatorze versos do poema, cuja única obra publicada, o "Só", é alçada à condição de Livro

\footnotetext{
${ }^{5}$ PESSOA, 1916, p. 63.

${ }^{6}$ QUINTANA, 1972, p. 24.

${ }^{7}$ QUINTANA, 1972, p. 10.
} 
Santo, porque faculta ao leitor viver na Torre de Anto... / Torre tão alta... em pleno azul erguida!...

A admiração por Antônio Nobre e pelo "Só" não se limitou a Mario Quintana. Desde o início do século, os poetas do Rio Grande do Sul manifestavam sua preferência por aquele autor. Alvaro Moreyra foi quem mais se aproximou afetiva e literariamente da poética de Nobre, conforme propõe Eduardo Guimaraens, companheiro de geração do cronista gaúcho:

Foi esse amor à tristeza que faz cantar, essa carícia à dor amada de sentir, esse desejo de exibir o próprio coração entre as mãos, que a princípio irmanou Alvaro Moreyra a Antônio Nobre.?

O próprio Alvaro Moreyra reconhece a importância que Antônio Nobre teve entre suas leituras:

A minha geração teve muitas influências. Mas ninguém, nela, ganhou mais mestres do que eu. Quase todos li depois de saber que eram meus mestres. Entretanto, se disser os nomes de Antônio Nobre e Jules Laforgue, não posso, para não mentir, dizer outros. ${ }^{10}$

Fernando Pessoa e Mario Quintana parecem ter feito percurso similar de leituras, ambos abeberando-se nos simbolistas, especialmente em Antônio Nobre, quando se trata do poeta gaúcho. O efeito foi, aparentemente, parecido: a opção pelo soneto como forma poética, a manifestação de uma poética em que o eu se percebe um outro, não por sair de si mesmo, mas por ser produto de um sujeito externo, anônimo e impessoal, que molda a subjetividade literária.

Em Fernando Pessoa, o resultado dessa metamorfose do eu em outro foi a criação dos heterônimos, que multiplicaram as possibilidades de o sujeito poético se entender e expressar enquanto alteridade autônoma e autosuficiente. Mario Quintana decidiu-se por outro caminho, não tão diversificado nas identidades, mas igualmente variado nas aparências. Não por acaso um de seus quartetos define a questão sob a ótica do humor e da ironia, uma das tônicas da linguagem do poeta:

${ }^{8}$ QUINTANA, 1972, p. 23.

${ }^{9}$ GUIMARAES, 1914, s. p.

${ }^{10}$ MOREYRA, [1958], p. 33. 
Tudo deu certo, meu velho Heráclito, porque eu sempre consigo atravessar esse teu outro rio como o meu eu eternamente outro... ${ }^{11}$

Coerente com a poética manifesta em seu primeiro soneto, Mario Quintana atravessa o rio do tempo na companhia de seus textos diversos, poemas tortos / que andei tentando endireitar em vão... ${ }^{12}$

\section{Referências Bibliográficas}

GUIMARAES, Eduardo. A vida literária: Alvaro Moreyra. In: O Diário. Porto Alegre, s. e., 1914. s. p.

MOREYRA, Alvado. As amargas, não... (Lembranças). 3. ed. Rio de Janeiro: Lux, s. d. [1958]. p. 33.

PESSOA, Fernando. Passos da Cruz. Quatorze sonetos. Centauro. Revista Trimestral de Literatura, Ano I, n. 1, p. 73, out.-nov.-dez. 1916. Edição facsimilada. Lisboa: Contexto, 1982.

QUINTANA, Mario. O poeta canta a si mesmo. Esconderijo do tempo. Porto Alegre: L\&PM, 1980.

QUINTANA, Mario. A rua dos cataventos. Poesias. 2. ed. Porto Alegre: Globo; Brasília: Instituto Nacional do Livro, 1972.

QUINTANA, Mario. Bilhete a Heráclito. A vaca e o hipogrifo. Porto Alegre: Garatuja, 1977. p. 36.

${ }^{11}$ QUINTANA,1977, p. 36.

${ }^{12}$ QUINTANA, 1972, p. 27. 


\section{Resumo}

Estudo da obra de Mário Quintana, vendo nela a diversidade e as relações com outros poetas.

\section{Résumé}

Étude de l'oeuvre de Mário Quintana, à partir de la diversité du poète e de quelques relations avec d'autres poètes. 